\title{
Anti-trypanosomal screening of Salvadoran flora
}

\author{
Ulises G. Castillo ${ }^{1}$ Ayato Komatsu² $\cdot$ Morena L. Martínez ${ }^{1} \cdot$ Jenny Menjívar ${ }^{3} \cdot$ Marvin J. Núñez $^{1} \cdot$ Yoshinori Uekusa $^{2}$. \\ Yuji Narukawa $^{2}$. Fumiyuki Kiuchi ${ }^{2}$. Junko Nakajima-Shimada ${ }^{4}$
}

Received: 29 June 2021 / Accepted: 31 August 2021 / Published online: 16 September 2021

(c) The Author(s) 2021

\begin{abstract}
Chagas disease is caused by the protozoan parasite Trypanosoma cruzi, and in Central America, it is considered one of the four most infectious diseases. This study aimed to screen the anti-trypanosomal activity of plant species from Salvadoran flora. Plants were selected through literature search for plants ethnobotanically used for antiparasitic and Chagas disease symptomatology, and reported in Museo de Historia Natural de El Salvador (MUHNES) database. T. cruzi was incubated for $72 \mathrm{~h}$ with 2 different concentrations of methanolic extracts of 38 species, among which four species, Piper jacquemontianum, Piper lacunosum, Trichilia havanensis, and Peperomia pseudopereskiifolia, showed the activity ( $\leq 52.0 \%$ viability) at $100 \mu \mathrm{g} / \mathrm{mL}$. Separation of the methanolic extract of aerial parts from Piper jacquemontianum afforded a new flavanone (4) and four known compounds, 2,2-dimethyl-6-carboxymethoxychroman-4-one (1), 2,2-dimethyl-6-carboxychroman-4-one (2), cardamomin (3), and pinocembrin (5), among which cardamomin exhibited the highest anti-trypanosomal activity $\left(\mathrm{IC}_{50}=66 \mu \mathrm{M}\right)$. Detailed analyses of the spectral data revealed that the new compound 4 , named as jaqueflavanone $\mathrm{A}$, was a derivative of pinocembrin having a prenylated benzoate moiety at the 8-position of the A ring.
\end{abstract}

\section{Graphic abstract}

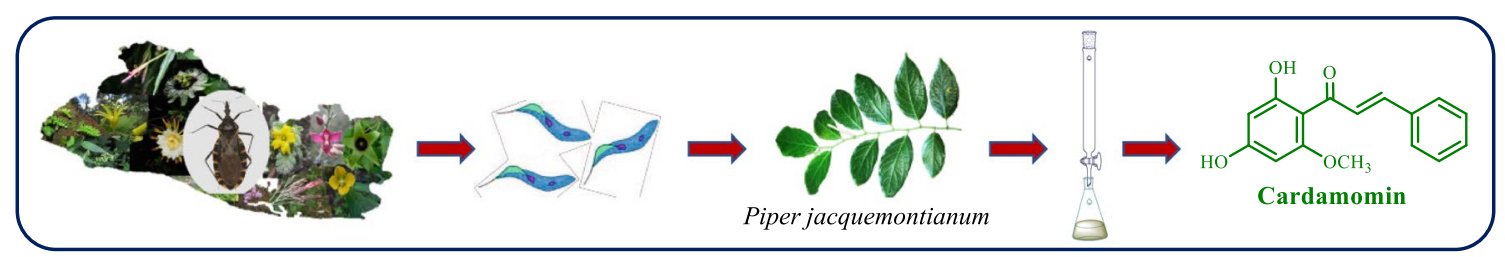

Keywords Chagas disease $\cdot$ Trypanosoma cruzi $\cdot$ Salvadoran flora $\cdot$ Piper jacquemontianum $\cdot$ Flavonoids

\section{Introduction}

Fumiyuki Kiuchi

kiuchi-fm84@keio.jp

1 Laboratorio de Investigación en Productos Naturales, Facultad de Química y Farmacia, Universidad de El Salvador, Final Av. de Mártires y Héroes del 30 de Julio, San Salvador 1101, El Salvador

2 Faculty of Pharmacy, Division of Natural Medicines, Keio University, 1-5-30 Shibakoen, Minato-ku, Tokyo, Tokyo 105-8512, Japan

3 Ministerio de Cultura, Museo de Historia Natural de El Salvador, San Salvador 1101, El Salvador

4 Graduate School of Health Sciences, Gunma University, 3-39-22 Showamachi, Maebashi, Gunma 371-8514, Japan
Chagas disease is considered the fourth highest burden of infectious diseases in Central America, behind HIV/AIDS, acute respiratory infections, and acute diarrheal diseases [1]. Trypanosoma cruzi has been identified as the causal agent of Chagas disease. This protozoan parasite is mainly transmitted through contact with the feces of hematophagous triatomine insects and infects a broad range of mammalian species including humans. In Latin America, Chagas disease continues to be an important public and social health problem, and the World Health Organization [2] considers it as one of the neglected tropical diseases (NTDs).

El Salvador has a population of 6.5 million and approximately $39 \%$ of the population is at risk of contracting this 
disease [3]. The latest official data on Chagas disease, from the Health's Ministry of El Salvador, conclude that between 2014 and 2017, 771 chronic cases and 53 acute cases were reported and the prevalence of $T$. cruzi in blood banks is among the highest in the Americas, fluctuating between 1.5 and $3.9 \%$ in 2008-2016 [1].

At present, Chagas disease is being treated mainly with nifurtimox (NF) and benznidazole (BNZ). Nifurtimox and benznidazole achieve cure rates of $70 \%$ and $75 \%$, respectively, in acute cases, and a $100 \%$ cure is obtained in congenital cases if the treatment is carried out during the first year of life. However, both drugs are administered for at least $30-60$ days and produce side effects in 30\% of the cases. Other drugs that have been administered are itraconazole and posaconazole. In acquired chronic cases, a $20 \%$ cure and $50 \%$ improvement of electrocardiographic changes are obtained with itraconazole [4].

The development of new, safer, and more effective trypanocidal drugs remains a current challenge, as drugs for Chagas disease are not considered a high priority by the R\&D-based pharmaceutical industry [5]. Throughout the history of mankind, natural products have been decisive for the discovery of new drugs, since they have enormous structural diversity as compared to conventional synthetic molecules and the screening of these natural sources remains one of the most attractive routes for this purpose [6, 7]. Various plant species have been tested in the search for natural products to combat Chagas disease caused by T. cruzi, exhibiting in many cases high trypanocidal activity and low toxicity [8-11].

The present work aimed to assess the in vitro activity of some Salvadoran plant extracts against the epimastigotes forms of $T$. cruzi. Thirty-eight species of plants belonging to 19 genera in 15 families were investigated. Trypanocidal activity was observed in the methanolic extracts obtained from Peperomia pseudopereskiifolia, Piper jacquemontianum, P. lacunosum (Piperaceae), and Trichilia havanensis (Meliaceae). Methanolic extract of aerial parts from $P$. jacquemontianum was fractionated, resulting in the isolation and structural elucidation of a new flavanone (4), together with four known compounds (1-3 and $\mathbf{5})$. Anti-trypanosomal activity of the isolated compounds was evaluated.

\section{Results and discussion}

Bibliographic research for plants ethnobotanically used for antiparasitic and Chagas disease symptomatology (fatigue, depression, constipation, and gastric pains) or heart complaints [12, 13], and reported in Museo de Historia Natural de El Salvador (MUHNES) database, resulted in 350 species. From these species, 97 species belonging to promising botanical families and genera, from which characteristic compounds of proven trypanocidal potential have been reported, were selected as candidates for anti-trypanosomal screening. Among these species, 38 species were collected and used for the screening (Table 1).

To carry out the anti-trypanosomal screening, $\mathrm{MeOH}$ extracts of collected plants were prepared. The yields of the extract ranged between $5.8-18.1 \%, 2.7-11.5 \%, 10.4-48.8 \%$, and $6.3 \%$ for aerial parts, leaves, stem bark, and roots, respectively. The activity of 38 plant species from El Salvador against $T$. cruzi is summarized in Fig. 1 (also see S3). Although there are no widely accepted criteria to consider a promising extract or compound [13], taking into account the criteria of Osorio et al. [14], an extract is considered moderately active if it reduces viablility of T. cruzi around 50\% at $100 \mu \mathrm{g} / \mathrm{mL}$. Among the 38 plant species, four species, Peperomia pseudopereskiifolia, Piper jacquemontianum, P. lacunosum (Piperaceae), and Trichilia havanensis (Meliaceae), showed moderate activity at $100 \mu \mathrm{g} / \mathrm{mL}$.

The Piperaceae family includes a large number of plants used in tropical and subtropical regions. The Piper and Peperomia genera are the most representative of this botanical family and Piper species are commonly used in LatinoAmerican traditional medicines for the treatment of protozoal diseases [15]. From the Piperaceae family, some species have been tested against $T$. cruzi and some bioactive compounds have been isolated such as flavonoids, terpenoids, lignans, chromanes, and alkaloids [13, 15, 16]. Concerning genus Peperomia, the main classes of compounds described are, phenylpropanoids, lignans, pyrones, aliphatic and aromatic amides, alkaloids, polyketides, benzoic acid derivatives, and chromenes, among which trypanocidal activity was reported for lignans and benzoic acid derivatives [17, 18].

Genus Trichilia has been studied for different biological activities, including trypanocidal activity [19, 20]. In a study of Meliaceae and Rutaceae family, the branches of T. ramalhoi were one of the most active extracts [21]. According to Pizzolatti et al. [19], the bark of $T$. catigua showed activity against trypomastigotes of $T$. cruzi. From $T$. havanensis some metabolites have been isolated, such as triterpenoids, tetranortriterpenoid, hydroxybutenolide derivative, and limonoids [22-24]. In a study carried out against Trypanosoma brucei, the bark extract of T. emetica showed activity attributed to the presence of limonoids [20].

In this study, we isolated the constituents of $P$. jacquemontianum. This plant is a shrub $1-4 \mathrm{~m}$ in high, and native to Central America and the Caribbean lowlands [25]. In various Latin American countries, $P$. jacquemontianum is used in folklore medicine to treat skin ailments, infections, anemia, and body aches [26, 27]. In Panama, it is traditionally used as a remedy for fever, headache, and cold, nervousness, diabetes, stomachache [28]. Chemical study of this species has been mainly performed on essential oils. Linalool and 
Table 1 List of Salvadoran plants collected to determine anti-trypanosomal activity

\begin{tabular}{|c|c|c|c|c|c|c|}
\hline No. & Family & Scientific name $^{1}$ & Vernacular name & Part $^{2}$ & Voucher number & Collection date/ place $^{3}$ \\
\hline 1 & Acanthaceae & Justicia carthagenesis Jacq. & "Hierba del susto" & A & J. Menjívar et al. 4264 & Jul 2018/1 \\
\hline 2 & Acanthaceae & Hypoestes phyllostachya Baker. & "Pecocita" & A & J. Menjívar et al. 4690 & May 2018/2 \\
\hline 3 & Aristolochiaceae & $\begin{array}{l}\text { Aristolochia salvadorensis } \\
\text { Standl. }\end{array}$ & "Guaco" & A & J. Menjívar et al. 5099 & Jun $2018 / 3$ \\
\hline 4 & Asteraceae & Baccharis trinervis Pers. & "Arroz con leche" & A & J. Menjívar et al. 4260 & Aug 2018/2 \\
\hline 5 & Boraginaceae & Ehretia latifolia Loisel & Unknown & $\mathrm{R}$ and $\mathrm{L}$ & J. Menjívar et al. 4633 & Aug 2018/4 \\
\hline 6 & Ebenaceae & $\begin{array}{l}\text { Diospyros salicifolia Humb. } \\
\text { and Bonpl. ex Willd. }\end{array}$ & Unknown & SB & J. Menjívar et al. 4262 & Jul 2018/1 \\
\hline 7 & Euphorbiaceae & Acalypha firmula Müll.Arg. & "Gusanito" & A & J. Menjívar et al. 4622 & Aug 2018/2 \\
\hline 8 & Euphorbiaceae & Acalypha setosa A.Rich & "Gusanito" & A & J. Menjívar \& M. Núñez 4263 & May 2018/5 \\
\hline 9 & Fabaceae & $\begin{array}{l}\text { Erythrina poeppigiana (Walp.) } \\
\text { O.F.Cook }\end{array}$ & "Pito extranjero" & $\mathrm{L}$ and $\mathrm{SB}$ & J. Menjívar et al. 4287 & Jul 2018/5 \\
\hline 10 & Fabaceae & $\begin{array}{l}\text { Lysiloma auritum (Schltdl.) } \\
\text { Benth. }\end{array}$ & "Quebracho" & SB & J. Menjívar et al. 4659 & Sept 2018/6 \\
\hline 11 & Fabaceae & Lysiloma divaricatum Jacq. & "Cicahuite" & SB & J. Menjívar et al. 4660 & Sept 2018/6 \\
\hline 12 & Fabaceae & $\begin{array}{l}\text { Mimosa albida Humb. and } \\
\text { Bonpl. ex Willd. }\end{array}$ & "Zarza" & A & J. Menjívar et al. 4597 & Jul 2018/4 \\
\hline 13 & Melastomataceae & Miconia argentea DC. & "Cirin" & $\mathrm{L}$ & J. Menjívar et al. 4261 & Aug 2018/2 \\
\hline 14 & Melastomataceae & Miconia guatemalensis Cogn. & "Cirin" & $\mathrm{L}$ & J. Menjívar et al. 4697 & Jul 2018/4 \\
\hline 15 & Melastomataceae & Miconia lauriformis Naudin & "Cirin" & $\mathrm{L}$ & J. Menjívar et al. 4614 & Aug 2018/2 \\
\hline 16 & Meliaceae & Trichilia havanensis Jacq. & "Barrehornos" & SB & J. Menjívar et al. 4977 & Jul 2018/1 \\
\hline 17 & Meliaceae & Trichilia havanensis Jacq. & "Barrehornos" & SB & J. Menjívar et al. 4221 & Aug 2018/2 \\
\hline 18 & Meliaceae & Trichilia hirta $\mathrm{L}$. & "Ceibillo" & SB & J. Menjívar et al. 4665 & Sept 2018/6 \\
\hline 19 & Meliaceae & Trichilia martiana C.DC. & "Barrehornos" & SB & J. Menjívar et al. 4227 & Aug 2018/2 \\
\hline 20 & Moraceae & Dorstenia drakena $\mathrm{L}$. & "Hierba del sapo" & A & J. Menjívar et al. 4252 & Jul 2018/1 \\
\hline 21 & Lauraceae & $\begin{array}{l}\text { Persea caerulea (Ruiz and Pav.) } \\
\text { Mez }\end{array}$ & "Aguamico" & SB & J. Menjívar et al. 4288 & Oct $2018 / 7$ \\
\hline 22 & Lauraceae & Persea schiedeana C.F.Gaertn. & "Chucte" & $\mathrm{L}$ and $\mathrm{SB}$ & J. Menjívar et al. 4205 & Nov 2018/5 \\
\hline 23 & Lauraceae & Persea standleyi C.K. Allen & "Guacamico" & SB & J. Menjívar et al. 4649 & Sept 2018/2 \\
\hline 24 & Piperaceae & $\begin{array}{l}\text { Peperomia obtusifolia (L.) } \\
\text { A.Dietr. }\end{array}$ & Unknown & A & J. Menjívar et al. 4599 & Jul 2018/4 \\
\hline 25 & Piperaceae & $\begin{array}{l}\text { Peperomia pseudopereskiifolia } \\
\text { C. DC. }\end{array}$ & Unknown & A & J. Menjívar et al. 4658 & Sept 2018/2 \\
\hline 26 & Piperaceae & Peperomia quadrifolia Miq. & Unknown & A & J. Menjívar et al. 4654 & Sept 2018/2 \\
\hline 27 & Piperaceae & Piper amalago $\mathrm{L}$ & Unknown & A & J. Menjívar et al. 4653 & Sept 2018/2 \\
\hline 28 & Piperaceae & Piper bredemeyeri J. Jacq. & Unknown & A & J. Menjívar et al. 4621 & Aug 2018/2 \\
\hline 29 & Piperaceae & Piper jacquemontianum Kunth & Unknown & A & J. Menjívar et al. 4247 & Jun $2018 / 3$ \\
\hline 30 & Piperaceae & Piper lacunosum Kunth & "Cordoncillo" & A & J. Menjívar et al. 4648 & Sept 2018/2 \\
\hline 31 & Piperaceae & Piper standleyi Trel. & "Cordoncillo" & A & J. Menjívar et al. 4598 & Jul 2018/4 \\
\hline 32 & Piperaceae & Piper xanthostachyum C. DC. & Unknown & A & J. Menjívar et al. 4655 & Sept 2018/2 \\
\hline 33 & Rutaceae & Zanthoxylum kellermanii & "Cedro espino" & $\mathrm{L}$ and $\mathrm{SB}$ & J. Menjívar et al. 4620 & Jul 2018/2 \\
\hline 34 & Sapindaceae & Exothea paniculate Radlk. & Unknown & $\mathrm{L}$ & J. Menjívar et al. 4660 & Sept 2018/2 \\
\hline 35 & Solanaceae & Solanum candidum Lindl. & Unknown & A & J. Menjívar et al. 4615 & Aug 2018/2 \\
\hline 36 & Solanaceae & Solanum lanceolatum Cav. & "Cuerno de vaca" & A & J. Menjívar et al. 4624 & Aug 2018/4 \\
\hline 37 & Solanaceae & Solanum myriacanthum Dunal & "Huevos de gato" & A & J. Menjívar et al. 4616 & Aug 2018/2 \\
\hline 38 & Solanaceae & Solanum torvum $\mathrm{Sw}$. & Unknown & A & J. Menjívar et al. 4618 & Aug 2018/2 \\
\hline
\end{tabular}

${ }^{1}$ Scientific names are given following international plant name index (IPNI)

${ }^{2} A$ arial parts; $L$ leaves; $S B$ stem bark; $R$ roots

${ }^{3}$ Collection place number: 1: PNA Bosque de Cinquera; 2: NP Montecristo; 3: NP El Imposible; 4: NP Complejo Los Volcanes; 5: Cantón El Jocotón; 6: Potonico; 7: Chinchontepec Volcano

$P N A$ protected natural area; $N P$ national park 


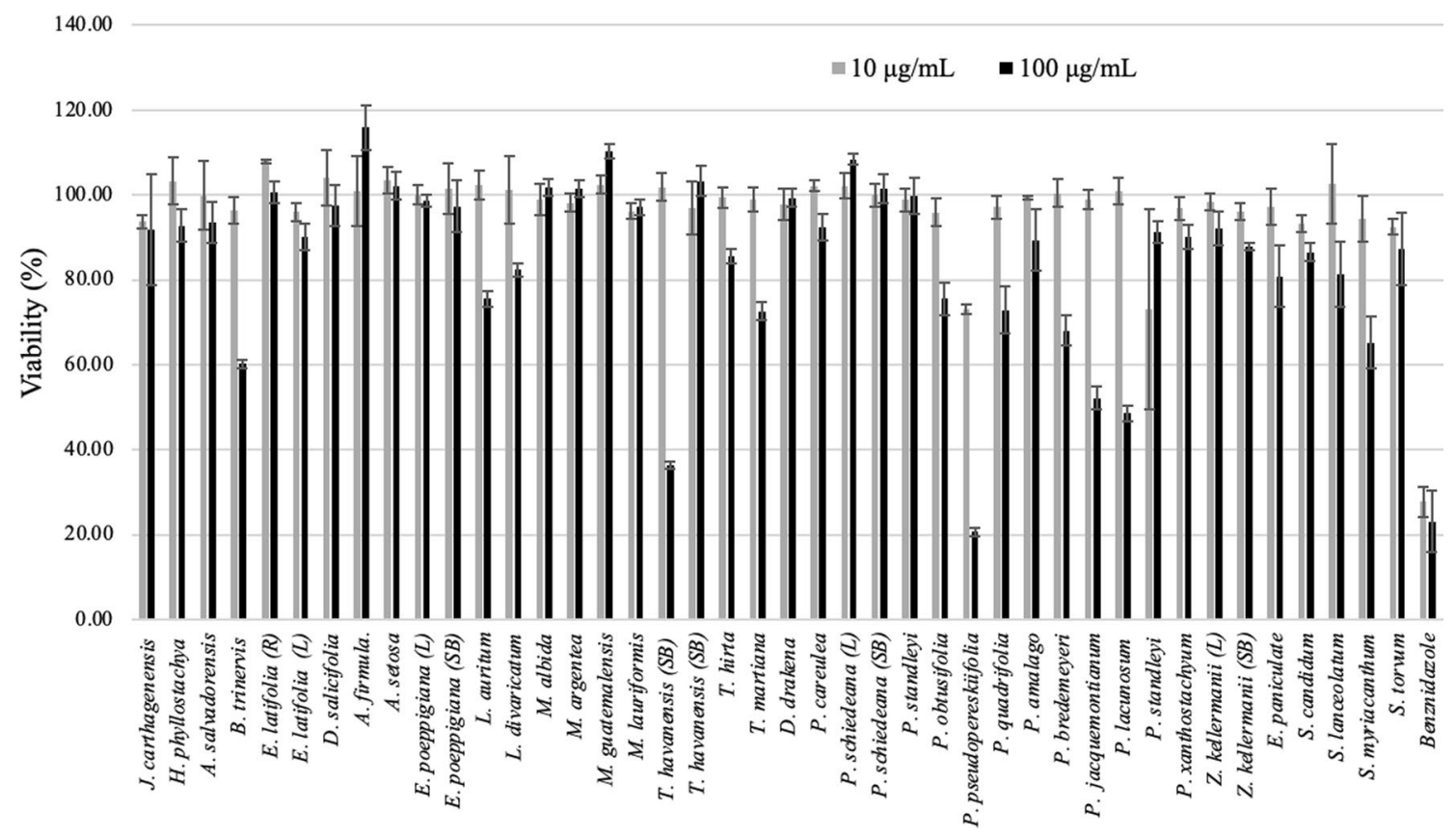

Fig. 1 Anti-trypanosomal activity of Salvadoran flora

$E$-nerolidol were reported as the major constituents of its essential oil [29, 30], whereas a recent study revealed that the composition was variable and only $E$-nerolidol was detected as a common constituent among the eight cultivars from different places in Guatemala [31]. Although linalool has been reported to show anti-trypanosomal activity [32], nothing has been reported on anti-trypanosomal constituents of the $\mathrm{MeOH}$ extract of this species.

Aerial parts of P. jaquemontianum $(510 \mathrm{~g})$ were extracted with $\mathrm{MeOH}$ at room temperature to give $83.5 \mathrm{~g}$ of the extract. As a preliminary experiment, the $\mathrm{MeOH}$ extract $(1.0 \mathrm{~g})$ was separated by a silica gel column chromatography with stepwise gradients of hexane and ethyl acetate and then $\mathrm{MeOH}$ to obtain nine fractions (D1-D9), among which D3-D6 inhibited the growth of epimastigotes of $T$. cruzi more than $50 \%$ at $100 \mathrm{mg} / \mathrm{mL}$. The major constituents of the active fractions were isolated to obtain compounds $\mathbf{1}$ (58 $\mathrm{mg}$ ) and 2 (8.6 $\mathrm{mg}$ ) from D4 and D6, respectively.

For further isolation of the constituents, the $\mathrm{MeOH}$ extract $(24.1 \mathrm{~g})$ was separated by silica gel column chromatography (hexane-AcOEt and then AcOEt-MeOH) to give nine fractions (E1-E9). Fractions E1, E4, E6, and E2, E3, E5 inhibited the growth of the epimastigotes more than $75 \%$ and $50 \%$, respectively, at $100 \mathrm{mg} / \mathrm{mL}$. From the major active fraction E4, compound $\mathbf{5}(6.3 \mathrm{mg})$ was obtained by silica gel column chromatography (hexane-AcOEt) and preparative HPLC (ODS, 75\% $\mathrm{MeOH}$ ). Separation of the other major fraction E5 by ODS $\left(\mathrm{MeOH}-\mathrm{H}_{2} \mathrm{O}\right)$ and silica gel (hexane-AcOEt) column chromatography and preparative HPLC $\left(\mathrm{CH}_{3} \mathrm{CN}-\mathrm{H}_{2} \mathrm{O}\right)$ to give compounds $3(47 \mathrm{mg})$ and 4 (2.4 mg). Compounds 2 and $\mathbf{1}$ were identified as 2,2-dimethyl-6-carboxychroman-4-one [30] and its methyl ester [29, 33], respectively, by comparison of their spectral data with those reported in the literature. It is the first time that these compounds were isolated from aerial parts of $P$. jacquemontianum.

Compounds $\mathbf{3}$ and $\mathbf{5}$ were also identified as cardamomin [34] and pinocembrin [35-37], respectively (Fig. 2). As compound $\mathbf{5}$ did not show significant optical rotation, it seems to be a racemic mixture. Pinocembrin and cardamomin have previously been isolated from Piper species [38-40].

The new compound 4 was obtained as white powder. Its ${ }^{1} \mathrm{H}$ NMR spectrum (Table 2) showed similar signals [ $\delta: 12.2(1 \mathrm{H}, \mathrm{s}, \mathrm{OH}), 7.44(3 \mathrm{H}$, overlapped, $\mathrm{H}-13, \mathrm{H}-14$, $\mathrm{H}-15), 7.39$ (2H, br d, $J=7.3 \mathrm{~Hz}, \mathrm{H}-12, \mathrm{H}-16), 5.45(1 \mathrm{H}$, br d, $J=13.2 \mathrm{~Hz}, \mathrm{H}-2), 3.09(1 \mathrm{H}, \mathrm{dd}, J=13.2,17.5 \mathrm{~Hz}$, $\mathrm{H}-3), 2.84(1 \mathrm{H}, \mathrm{dd}, J=2.0,17.5 \mathrm{~Hz}, \mathrm{H}-3)]$ with those of pinocembrin $(5)$ except that only a singlet $[6.07(1 \mathrm{H}, \mathrm{br} \mathrm{s}$, H-6)] was observed for ring A, indicating that compound 4 is a derivative of pinocembrin (5) having a substituent on the A ring. The spectrum also showed signals of a trisubstituted benzene ring [8.01 $\left(1 \mathrm{H}\right.$, br s, $\left.\mathrm{H}-3^{\prime}\right), 7.81(1 \mathrm{H}$, br d, $\left.J=8.3 \mathrm{~Hz}, \mathrm{H}-7^{\prime}\right), 6.83$ (1H, d, $\left.\left.J=8.3 \mathrm{~Hz}, \mathrm{H}-6^{\prime}\right)\right]$, a methoxy group [3.85 (3H, s, H-13')], and a prenyl group [1.79 (3H, s, H-12'), 1.68 (3H, s, H-11'), $5.98(1 \mathrm{H}, \mathrm{br}$ d, $\left.\left.J=8.2 \mathrm{~Hz}, \mathrm{H}-9^{\prime}\right), 5.39\left(1 \mathrm{H}, \mathrm{d}, J=8.2 \mathrm{~Hz}, \mathrm{H}-8^{\prime}\right)\right]$. These signals, together with the ${ }^{13} \mathrm{C}$ NMR signals and the HMQC correlations (Table 2), suggested that the substituent on the A ring is a prenylated methyl benzoate derivative. 
<smiles>COC(=O)c1ccc2c(c1)C(=O)CC(C)(C)O2</smiles><smiles>CC1(C)CC(=O)c2cc(C(=O)O)ccc2O1</smiles><smiles>COc1cc(O)cc(O)c1C(=O)/C=C/c1ccccc1</smiles><smiles>O=C1CC(c2ccccc2)Oc2cc(O)cc(O)c21</smiles><smiles>COC(=O)c1ccc(O)c(C(C=C(C)C)c2c(O)cc(O)c3c2OC(c2ccccc2)CC3=O)c1</smiles>

4

Fig. 2 Structures of isolated compounds from P. jaquemontianum

The connectivity of these groups was concluded from the HMBC correlations as shown in Fig. 3. The HMBC spectrum also showed correlations from the methine proton [5.39 $\left.\left(1 \mathrm{H}, \mathrm{d}, J=8.2 \mathrm{~Hz}, \mathrm{H}-8^{\prime}\right)\right]$ of the prenyl group to $\mathrm{C}-7$, C-8 and C-9 carbons of the ring A of pinocembrin moiety (Fig. 3), confirming the substitution position of this group at the 8-position on the A ring. Thus, the structure of compound 4 was concluded as shown in Fig. 2. Flavanones and prenylated benzoic acid derivatives [30, 35, 41-43] have been reported from various Piper species. However, a compound having both of these moieties has not been reported. As this is a new compound, it is named as jaqueflavanone A. In the HPLC purification of this compound, the presence of a closely related compound was observed. The ${ }^{1} \mathrm{H}$ NMR spectrum of a mixture of this compound and compound 4 suggested that it is a diastereomer of compound 4. However, this compound could not be obtained as a single compound. Compound $\mathbf{4}$ has two asymmetric carbons (C-2 and C-8'). As pinocembrin isolated from this extract was a racemic mixture, the stereochemistry of C-2 seems racemic. However, the stereochemistry of the other carbon could not be determined.

The $\mathrm{IC}_{50}$ values of the isolated compounds against epimastigotes of $T$. cruzi were $1.28 \mathrm{mM}(\mathbf{1}),>2 \mathrm{mM}$ (2), $66 \mu \mathrm{M}(3), 100 \mu \mathrm{M}$ (4), and $714 \mu \mathrm{M}$ (5). Cardamomin (3) has been reported to show trypanocidal activity against Trypanosoma brucei [44]. Synthesis and anti-trypanosomal activity of chalcone derivatives $[45,46]$ and chalconebased compounds [47-49] have been reported.
Table 2 NMR data of compound 4 in $\mathrm{CDCl}_{3}$

\begin{tabular}{|c|c|c|c|}
\hline Position & $13 \mathrm{C}$ & $1 \mathrm{H}$ & HMBC \\
\hline 2 & 79.9 & $\mathrm{~g}: 5.45,1 \mathrm{H}$, br d (13.2) & $\mathrm{d}, \mathrm{k} 1$ \\
\hline 3 & 43.4 & $\begin{array}{l}\text { c: } 2.84,1 \mathrm{H}, \mathrm{dd}(2.0,17.5) \\
\text { d: } 3.09,1 \mathrm{H}, \mathrm{dd}(13.2,17.5)\end{array}$ & \\
\hline 4 & 196.2 & & $\mathrm{c}, \mathrm{d}$ \\
\hline 5 & 162.5 & & $\mathrm{i}, \mathrm{n}$ \\
\hline 6 & 97.7 & i: $6.07,1 \mathrm{H}$, br s & $\mathrm{n}$ \\
\hline 7 & 162.7 & & $\mathrm{f}, \mathrm{i}$ \\
\hline 8 & 108.8 & & $a, b, f, i$ \\
\hline 9 & 159.6 & & f \\
\hline 10 & 103.5 & & $\mathrm{i}, \mathrm{n}$ \\
\hline 11 & 138.0 & & $\mathrm{~d}, \mathrm{~g}, \mathrm{k} 2$ \\
\hline 12 & 126.1 & k1: $7.39,1 \mathrm{H}$, br d $(7.3)$ & $\mathrm{g}, \mathrm{k} 2$ \\
\hline 13 & 128.9 & k2: $7.44,1 \mathrm{H}$, overlapped & $\mathrm{k} 1$ \\
\hline 14 & 126.0 & k2: $7.44,1 \mathrm{H}$, overlapped & k1 \\
\hline 15 & 128.9 & k2: $7.44,1 \mathrm{H}$, overlapped & k1 \\
\hline 16 & 126.1 & k1: $7.39,1 \mathrm{H}$, br d $(7.3)$ & $\mathrm{g}, \mathrm{k} 2$ \\
\hline 1 ' & 167.5 & & $\mathrm{e}, 1, \mathrm{~m}$ \\
\hline $2^{\prime}$ & 128.5 & & $f, j$ \\
\hline $3{ }^{\prime}$ & 131.3 & $\mathrm{~m}: 8.01,1 \mathrm{H}, \mathrm{br} \mathrm{s}$ & $\mathrm{f}, 1$ \\
\hline $4^{\prime}$ & 122.1 & & $\mathrm{j}, \mathrm{m}$ \\
\hline 5 & 158.2 & & $\mathrm{f}, \mathrm{j}, 1, \mathrm{~m}$ \\
\hline $6{ }^{\prime}$ & 116.0 & $\mathrm{j}: 6.83,1 \mathrm{H}, \mathrm{d}(8.3)$ & \\
\hline 7 ' & 129.7 & 1: $7.81,1 \mathrm{H}$, br d $(8.3)$ & $\mathrm{m}, \mathrm{f}$ \\
\hline $8^{\prime}$ & 33.6 & f: $5.39,1 \mathrm{H}, \mathrm{d}(8.2)$ & $\mathrm{j}, \mathrm{h}, \mathrm{m}$ \\
\hline 9' & 122.9 & h: $5.98,1 \mathrm{H}$, br d $(8.2)$ & $a, b, f$ \\
\hline $10^{\prime}$ & 136.1 & & $a, b, f$ \\
\hline $11^{\prime}$ & 18.2 & a: $1.68,3 \mathrm{H}, \mathrm{s}$ & $\mathrm{b}, \mathrm{h}$ \\
\hline $12^{\prime}$ & 25.9 & b: $1.79,3 \mathrm{H}, \mathrm{s}$ & $\mathrm{a}, \mathrm{h}$ \\
\hline $13^{\prime}$ & 52.0 & $\mathrm{e}: 3.85,3 \mathrm{H}, \mathrm{s}$ & \\
\hline $5-\mathrm{OH}$ & - & $\mathrm{n}: 12.2,1 \mathrm{H}, \mathrm{s}$ & \\
\hline
\end{tabular}

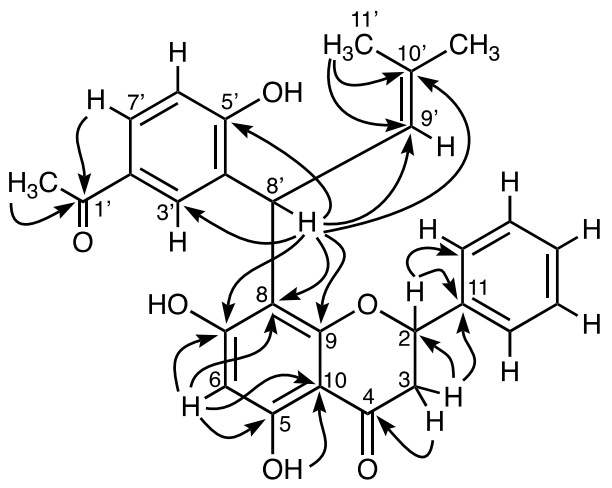

Fig. 3 Selected key HMBC correlations of compound 4 


\section{Conclusion}

In the present study, in vitro anti-trypanosomal activities of thirty-eight species from Salvadoran flora are reported. The most active methanolic extracts were from Peperomia speudopereskiifolia (Piperaceae), Trichilia havanensis (Meliaceae), Piper lacunosum (Piperaceae), and Piper jacquemontianum (Piperaceae). These results confirmed the effectiveness of the ethnobotanically used plants. The activity-guided fractionation of $P$. jacquemontianum resulted in the isolation of anti-trypanosomal compounds including cardamomin, whose activity against Trypanosoma has been reported. Constituents of the other active species are now under investigation.

Considering these findings, we can conclude that Salvadoran flora is a potential source of anti-trypanosomal substances and that the most promising extracts are potential sources of compounds for the development of more effective drugs for the treatment of Chagas disease. Translation of some in vitro results into in vivo follow-up studies is recommended in the future.

\section{Materials and methods}

\section{Apparatus}

ESI-TOFMS spectra were obtained with a JMS-T100LP AccuTOF LC-plus (JEOL, Tokyo, Japan) operated in negative ion mode. NMR spectra were recorded on an AVANCE 500 spectrometer (Bruker, MA, USA). Tetramethylsilane (TMS) was used as an internal standard. For HPLC profile analysis of crude extracts, a chromatographic system consisted of an LC-2010A HT (Shimadzu Co., Kyoto, Japan) liquid chromatography module equipped with SPD-M30A PDA detector set at 190-700 nm was used. The data were collected and processed using LabSolutions system (Shimadzu Co., Kyoto, Japan). Separation was performed in a column CAPCELL PAK C18 (TYPE: MGII, $2.0 \times 150 \mathrm{~mm}, 5 \mathrm{~mm}$, Shiseido, Tokyo, Japan) at $40^{\circ} \mathrm{C}$. The mobile phase consisted of water (solvent A) and acetonitrile (solvent B), both containing $0.1 \%$ ( $\mathrm{v} / \mathrm{v}$ ) of formic acid, with a flow rate of $0.2 \mathrm{~mL} / \mathrm{min}$. Linear gradient time program was set as follows: $0 \mathrm{~min}, 15 \% \mathrm{~B} ; 0-3 \mathrm{~min}$, $15 \%$ B; 3-37 min, $100 \%$ B; 37-42 min, 100\% B. For preparative HPLC, an HPLC system (Shimadzu Co., Kyoto, Japan) equipped with a LC-10ADvp HPLC pump and an SPD-10Avp UV/Vis detector was used. HPLC conditions for the separation are as follows: column, CAPCELL PAK C18 (10 mm i.d. $\times 150 \mathrm{~mm}, 5 \mathrm{~mm}$; Shiseido, Tokyo, Japan); mobile phase, 50\% MeCN (0 min)-60\% MeCN
(30 min) (gradient elution, condition 1), 75\% $\mathrm{MeOH}$ (isocratic elution, condition 2); flow rate, $2.5 \mathrm{~mL} / \mathrm{min}$; UV detection, $254 \mathrm{~nm}$.

\section{Plant selection process}

Bibliographic research was done to look for Salvadoran plants with ethnobotanical uses for antiparasitic and Chagas disease symptomatology (fatigue, depression, constipation, gastric pains) or heart complaints $[12,13]$, resulting in 380 possible plant species. The selection was limited to the plant species reported in Museo de Historia Natural de El Salvador (MUHNES) database, resulting in 350 species. These species were investigated in scientific journals database to find promising botanical families and genera from which bioactive compounds have been reported, moreover, the plants are known to contain characteristic compounds of proven trypanocidal potential. Ninety-seven species resulted as a possible anti-trypanosomal species.

\section{Plant materials}

From the 97 possible species, only thirty-eight species were possible to collect for anti-trypanosomal screening. They were collected under the permission and resolution code MARN-DEV-GVS-040-2018 at protected natural areas of El Salvador in 2018 and identified by Jenny Elizabeth Menjívar Cruz, Curator of the Herbarium at the Museo de Historia Natural de El Salvador (Table 1). A voucher specimen has been deposited for each species in the Herbarium at the MUHNES.

To carried out the bioassay-guided isolation, the aerial parts of Piper jacquemontianum Kunth were collected at El Imposible National Park, Ahuachapán, El Salvador (latitude:1349'49" N, longitude: $89^{\circ} 56^{\prime} 33^{\prime}$ " W, elevation: $816 \mathrm{~m}$ ) in June 2019 and the respective voucher (J. Menjivar et al. 4247) specimen has been deposited in the herbarium at MUHNES.

\section{Preparation of plant extracts}

The collected plants were dried at $40{ }^{\circ} \mathrm{C}$ for $48-72 \mathrm{~h}$ in a circulating air oven (BIOBASE, China, model BOV-V225F) and milled to obtain a particle size $\leq 2 \mathrm{~mm}$ (Bel-Art products, USA, model micro-mill). Twenty grams of each sample were extracted with methanol $(200 \mathrm{~mL} \times 2)$ in a magnetic stirrer ultrasonic bath (VWR, USA, model 97,043-988, operating frequency at $35 \mathrm{kHz}$ ) for $90 \mathrm{~min}$ at $25{ }^{\circ} \mathrm{C}$. Each extract was concentrated under reduced pressure at $40{ }^{\circ} \mathrm{C}$ (model RE801, Yamato Scientific Co., Ltd., Japan) to obtain the $\mathrm{MeOH}$ extracts. 


\section{Sample preparation for HPLC profile of crude extracts}

Each extract $(10.0 \mathrm{mg})$ was dissolved in $1 \mathrm{~mL}$ of methanol, using an ultrasonic bath (VWR, model 97,043-988, operating frequency at $35 \mathrm{kHz}$ ) at room temperature. A solution of $1 \mathrm{mg} / \mathrm{mL}$ was prepared for each extract solution using methanol. The sample solution was filtrated through a $0.45 \mu \mathrm{m}$ membrane filter before being subjected to HPLC analysis. HPLC profiles of the extracts are shown in the supplemental materials (Figure S7).

\section{Anti-trypanosomal screening of crude extracts (MTT method)}

Ninety-five microliters of epimastigotes $\left(3 \times 10^{6}\right.$ epimastigotes/mL, Tulahuen strain) suspended in GIT medium supplemented with hemin $(12.4 \mu \mathrm{M})$ were added in each well of 96 -well plate. These were incubated at $28{ }^{\circ} \mathrm{C}$ for $72 \mathrm{~h}$, after the addition of $5 \mathrm{~mL}$ of extracts $(100$ and $10 \mu \mathrm{g} / \mathrm{mL}$ in DMSO). Benznidazole was used as a positive control. After the incubation time, $10 \mu \mathrm{L}$ of MTT reagent $(5 \mathrm{mg} / \mathrm{mL}$ in PBS) was added to each well and incubated for another $24 \mathrm{~h}$. The medium was discarded and the precipitates of formazan were dissolved with $100 \mu \mathrm{L}$ of DMSO. The measurement of absorbance was performed at $530 \mathrm{~nm}$.

\section{Anti-trypanosomal test for fractions and isolated compounds (luminescence method)}

Epimastigotes of T. cruzi $\left(1 \times 10^{5}\right.$ parasites/well $)$ in GIT medium $(50 \mu \mathrm{L})$ and a sample dissolved in DMSO $(0.5 \mathrm{~mL})$ were added to each well of a 384-well white plate (Falcon, $353,988)$. The plate was incubated at $27^{\circ} \mathrm{C}$ for $24 \mathrm{~h}$. After the incubation, $20 \mu \mathrm{L}$ of CellTiter-Glo reagent (Promega, G7570) were added to each well and the intensity of luminescence $(500-670 \mathrm{~nm})$ was measured by a luminometer (Infinite M200 Pro, Tecan). To compensate for the luminescence of the sample itself, each sample solution in GIT medium without epimastigotes was used as a blank. Tamoxifen was used as a positive control $\left(\mathrm{IC}_{50} 19.3 \mathrm{mM}\right)$. To determine $\mathrm{IC}_{50}$ values, six different concentrations of each sample were prepared.

\section{Extraction and isolation of Piper jacquemontianum}

The dried and ground aerial parts of Piper jacquemontianum $(510.0 \mathrm{~g})$ were extracted with $\mathrm{MeOH}(3 \times 5 \mathrm{~L}, 14$ days each) at room temperature, and concentrated using a rotary evaporator, yielding a crude extract $(83.46 \mathrm{~g})$. A part of the $\mathrm{MeOH}$ extract of $P$. jaquemontianum $(1.0 \mathrm{~g})$ was subjected to silica gel column chromatography $(4 \times 15 \mathrm{~cm})$ and successively eluted with hexane: AcOEt $=100: 0,90: 10,70: 30,50: 50$,
30:70, 10:90, 0:100, then AcOEt: $\mathrm{MeOH}=50: 50,0: 100$ to give fractions D1 (6.7 mg), D2 (30.6 mg), D3 (20.4 mg), D4 (129.7 mg), D5 (50.5 mg), D6 (68.5 mg), D7 (27.6 mg), D8 $(221.1 \mathrm{mg})$, and D9 $(158.8 \mathrm{mg})$. A part of fraction D4 $(115 \mathrm{mg})$ was fractionated by silica gel column chromatography $(3 \times 25 \mathrm{~cm})$ with hexane: $\mathrm{AcOEt}=19: 1$ to give D4-1 (0.3 mg), D4-2 (58.4 mg), D4-3 (10.2 mg), D4-4 (52.6 mg), D4-5 (3.2 mg), D4-6 (4.0 mg), D4-7 (5.4 mg), D4-8 $(6.3 \mathrm{mg})$, and D4-9 $(15.7 \mathrm{mg})$. Fraction D4-2 was crystallized from hexane-EtOH to give 2,2-dimethyl-6-carbomethoxychroman-4-one (1). Fraction D6 (34.0 mg) was separated by ODS column chromatography $(1.5 \times 15 \mathrm{~cm})$ with $\mathrm{H}_{2} \mathrm{O}: \mathrm{MeOH}=1: 1$, and then $100 \% \mathrm{MeOH}$ to give fractions D6-1 (4.6 mg), D6-2 (8.6 mg), D6-3 (0.3 mg), D6-4 $(1.2 \mathrm{mg}), \mathrm{D} 6-5(1.9 \mathrm{mg})$, and D6-6 (3.0 mg). Fraction D6-2 was crystallized from hexane-EtOH to give 2,2-dimethyl6-carboxychroman-4-one (2).

A part of the $\mathrm{MeOH}$ extract of $P$. jaquemontianum $(24.1 \mathrm{~g})$ was fractionated by silica gel column chromatography $(6 \times 22 \mathrm{~cm})$ and successively eluted with hexane: $\mathrm{AcOEt}=100: 0$, 90:10, 70:30, 50:50, 30:70, 10:90, 0:100, and AcOEt: $\mathrm{MeOH}=50: 50,0: 100$ to give 9 fractions: E1 (107.2 mg), E2 (930.0 mg), E3 (3.1 g), E4 (2.1 g), E5 (2.1 g), E6 (819.5 mg), E7 (621.3 mg), E8 (4.5 g), and E9 $(4.0 \mathrm{~g})$. The major fraction E4 (2.1 g) was separated by silica gel column chromatography $(4 \times 15 \mathrm{~cm})$ with hexane: $\mathrm{AcOEt}=4: 1,2: 1$, and then $100 \% \mathrm{MeOH}$ to give fractions E4-1 (5.7 mg), E4-2 (11.8 mg), E4-3 (601.0 mg), E4-4 (70.6 mg), E4-5 (136.5 mg), E4-6 (206.6 mg), E4-7 (194.0 mg), and E4-8 (565.2 mg). Fraction E4-5 (14.2 mg) was purified by HPLC (HPLC condition 2) to give fractions E4-5-1 (6.3 mg) and E4-5-2 (5.0 mg). Fraction E4-5-1 was crystallized from $\mathrm{MeOH}$ to give pinocembrin (5). Fraction E5 $(2.1 \mathrm{~g})$ was subjected to an ODS column chromatography $(4 \times 15 \mathrm{~cm})$ and eluted with $\mathrm{H}_{2} \mathrm{O}: \mathrm{MeOH}=1: 1$, then $100 \%$ $\mathrm{MeOH}$ to give fractions E5-1 (116.6 mg), E5-2 (665.5 mg), E5-3 (404.7 mg), E5-4 (122.2 mg), E5-5 (231.2 mg), E5-6 (39.0 mg), and E5-7 (289.9 mg). Fraction E5-2 was identified as 2,2-dimethyl-6-carboxychroman-4-one (2). Fraction E5-4 was fractionated by silica gel column chromatography $(3 \times 20 \mathrm{~cm})$ with hexane: $\mathrm{AcOEt}=2: 1$, and then $100 \% \mathrm{MeOH}$ to give fractions E5-4-1 (47.3 mg), E5-4-2 (12.4 mg), and E5-4-3 (19.3 mg). Fraction E5-4-1 was crystallized from $\mathrm{MeOH}$ to give cardamomin (3). Fraction E5-4-2 (10.8 mg) was separated by preparative HPLC (HPLC condition 1) to give compound 4 (2.4 mg).

Jaqueflavanone A (4): white powder, $\mathrm{mp} 133-135^{\circ} \mathrm{C}$; HR-ESI-TOFMS (neg.) $\mathrm{m} / \mathrm{z} 473.1592[\mathrm{M}-\mathrm{H}]{ }^{-}$(calcd. for $\left.\mathrm{C}_{28} \mathrm{H}_{25} \mathrm{O}_{7}, 473.1600\right) ;{ }^{1} \mathrm{H}$ NMR (500 MHz, $\mathrm{CDCl}_{3}$ ) $\delta: 12.2$ $(1 \mathrm{H}, \mathrm{s}, \mathrm{OH}), 8.01(1 \mathrm{H}, \mathrm{br} \mathrm{s}, \mathrm{H}-3$ '), $7.81(1 \mathrm{H}, \mathrm{br} \mathrm{d}, J=8.3 \mathrm{~Hz}$, H-7'), 7.44 (3H, overlapped, H-13/15, H-14), 7.39 (2H, br d, $J=7.3 \mathrm{~Hz}, \mathrm{H}-12 / 16), 6.83$ (1H, d, $J=8.3 \mathrm{~Hz}, \mathrm{H}-6$ '), 6.07 (1H, br s, H-6), 5.98 (1H, br d, J=8.2 Hz, H-9'), 5.45 (1H, 
br d, $J=13.2 \mathrm{~Hz}, \mathrm{H}-2), 5.39$ (1H, d, $J=8.2 \mathrm{~Hz}, \mathrm{H}-8$ '), 3.85 (3H, s, H-13'), 3.09 (1H, dd, $J=13.2,17.5 \mathrm{~Hz}, \mathrm{H}-3), 2.84$ $(1 \mathrm{H}, \mathrm{dd}, J=2.0,17.5 \mathrm{~Hz}, \mathrm{H}-3), 1.79$ (3H, s, H-12'), 1.68 (3H, s, H-11'). ${ }^{13} \mathrm{C}$ NMR (125 MHz, $\mathrm{CDCl}_{3}$ ) $\delta: 196.2$ (C-4), 167.5 (C-1'), 162.7 (C-7), 162.5 (C-5), 159.6 (C-9), 158.2 (C-5'), 138.0 (C-11), 136.1 (C-10'), 131.3 (C-3'), 129.7 (C-7'), 128.9 (C-13), 128.5 (C-2'), 126.1 (C-12), 126.0 (C-14), 122.9 (C-9'), 122.1 (C-4'), 116.0 (C-6'), 108.8 (C-8), 103.5 (C-10), 97.7 (C-6), 79.9 (C-2), 52.0 (C-13'), 43.4 (C-3), 33.6 (C-8'), 25.9 (C-12'), 18.2 (C-11').

Supplementary Information The online version contains supplementary material available at https://doi.org/10.1007/s11418-021-01562-6.

Acknowledgements This work was supported by Grant for Science and Technology Research Partnership for Sustainable Development (SATREPS) from Japan Agency for Medical Research and Development (AMED) (JP: 19jm0110016h0303 and JP: 20jm20jm0110016h0004 to JS) and Japan International Cooperation Agency (JICA).

Open Access This article is licensed under a Creative Commons Attribution 4.0 International License, which permits use, sharing, adaptation, distribution and reproduction in any medium or format, as long as you give appropriate credit to the original author(s) and the source, provide a link to the Creative Commons licence, and indicate if changes were made. The images or other third party material in this article are included in the article's Creative Commons licence, unless indicated otherwise in a credit line to the material. If material is not included in the article's Creative Commons licence and your intended use is not permitted by statutory regulation or exceeds the permitted use, you will need to obtain permission directly from the copyright holder. To view a copy of this licence, visit http://creativecommons.org/licenses/by/4.0/.

\section{References}

1. Peterson JK, Yoshioka K, Hashimoto K, Caranci A, Gottdenker N, Monroy C, Saldaña A, Rodriguez S, Dorn P, Zúñiga C (2019) Chagas disease epidemiology in Central America: an update. Curr Trop Med Rep 6:92-105. https://doi.org/10.1007/ s40475-019-00176-z

2. WHO (2010) First WHO report on neglected tropical diseases: working to overcome the global impact of neglected tropical diseases. World Health Organization, Geneva (WHO/HTM/ NTD/2010)

3. Carmona-Galindo VD, Recinos MMF, Hidalgo GSA, Paredes RG, Vaquerano PEE, Magaña RAL, Ayala CAC (2020) Morphological variability and ecological characterization of the Chagas disease vector Triatoma dimidiata (Hemiptera: Reduviidae) in El Salvador. Acta Trop 205:105392. https://doi.org/10.1016/j.actatropica. 2020.105392

4. Apt W (2010) Current and developing therapeutic agents in the treatment of Chagas disease. Drug Des Dev Ther 4:243-253. https://doi.org/10.2147/dddt.s8338

5. Troullier P, Olliaro P, Torreele E, Orbinski J, Laing R, Ford N (2002) Drug development for neglected diseases: a deficient market and a public health policy failure. Lancet 359:2188-2194. https://doi.org/10.1016/S0140-6736(02)09096-7

6. Paloque L, Triastuti A, Bourdy G, Haddad M (2018) Natural products as antiparasitic agents. In: Mérillon JM, Riviere C (eds)
Natural antimicrobial agents, vol 19. Springer, Cham. https://doi. org/10.1007/978-3-319-67045-4_9

7. Atanasov AG, Zotchev SB, Dirsh VM, Supuran CT (2021) Natural products in drug discovery: advances and opportunities. Nat Rev Drug Discov 20:200-216. https://doi.org/10.1038/ s41573-020-00114-Z

8. Molina-Garza ZJ, Bazaldúa-Rodríguez AF, Quintanilla-Licea R, Galaviz-Silva L (2014) Anti-trypanosoma cruzi activity of 10 medicinal plants used in northeast Mexico. Acta Trop 136:14-18. https://doi.org/10.1016/j.actatropica.2014.04.006

9. Teixeira TL, Teixeira SC, da Silva CV, de Sousa MA (2014) Potential therapeutic use of herbal extracts in trypanosomiasis. Pathogens Glob Health 108:30-36. https://doi.org/10.1179/20477 73213Y.0000000120

10. Okba MM, Sabry OM, Matheeussen A, Abdel-Sattar E (2018) In vitro antiprotozoal activity of some medicinal plants against sleeping sickness, Chagas disease and leishmaniasis. Future Med Chem 10:2607-2617. https://doi.org/10.4155/fmc-2018-0180

11. Salm A, Krishnan SR, Collu M, Danton O, Hamburger M, Leonti M, Almanza G, Gertsch J (2021) Phylobioactive hotspots in plant resources used to treat Chagas disease. iScience 24:102310. https://doi.org/10.1016/j.isci.2021.102310

12. Ayala JC (2002) Etnobotánica medicinal de El Salvador, 2 (edn). Cuscatlania, El Salvador

13. Muschietti L, Sülsen V, Martino V (2013) Chapter 9-bioprospection of potential trypanocidal drugs: a scientific literature survey over the period. In: Rahman A (ed) Studies in natural products chemistry, vol 39. Elsevier, pp 297-336

14. Osorio E, Arango GJ, Jiménez N, Alzate F, Ruiz G, Gutiérrez D, Paco MA, Giménez A, Robledo S (2007) Antiprotozoal and cytotoxic activities in vitro of Colombian Annonaceae. J Ethnopharmacol 111:630-635. https://doi.org/10.1016/j.jep.2007.01.015

15. Vásquez-Ocmín PG, Gadea A, Cojean S, Marti G, Pomel S, Baele AC, Ruíz-Vásquez L, Mesia W, Figadère B, Mesia L, Maciuk A (2021) Metabolomic approach of the antiprotozoal activity of medicinal Piper species used in Peruvian Amazon. J Ethnopharmacol 264:113262. https://doi.org/10.1016/j.jep.2020.113262

16. Batista JM Jr, Lopes AA, Ambrósio DL, Regasini LO, Kato MJ, Bolzani VdS, Cicarelli RMB, Furlan M (2008) Natural chromenes and chromene derivatives as potential anti-trypanosomal agents. Biol Pharm Bull 31:538-540. https://doi.org/10.1248/bpb.31.538

17. Felippe L, Baldoqui DC, Kato MJ, Bolzani VS, Guimarães EF, Cicarelli RM, Furlan M (2008) Trypanocidal tetrahydrofuran lignans from Peperomia blanda. Phytochem 69:445-450. https://doi. org/10.1016/j.phytochem.2007.08.012

18. Chouna HS, Bankeu JJ, Fongang YS, Dize D, Ponou BK, Bitchagno GT, Awantu AF, Lenta BN, Fekam F, Ngouela S, Opatz T, Sewald N (2021) Constituents of Peperomia vulcanica Baker \& C. H. Wright (Piperaceae) with antiparasitic activity. Phytochem Lett 41:14-20. https://doi.org/10.1016/j.phytol.2020.10.010

19. Pizzolatti MG, Koga AH, Grisard EC, Steindel M (2002) Trypanocidal activity of extracts from Brazilian Atlantic rain forest plant species. Phytomed 9:422-426. https://doi.org/10.1078/ 0944-7113-00252

20. Komane B, Olivier E, Viljoen A (2011) Trichilia emetica (Meliaceae) - a review of traditional uses, biological activities, and phytochemistry. Phytochem Lett 4:1-9. https://doi.org/10. 1016/j.phytol.2010.11.002

21. Ambrozin AR, Vieira PC, Fernandes JB, da Silva MF, de Albuquerque S (2004) Trypanocidal activity of Meliaceae and Rutaceae plant extracts. Mem Inst Oswaldo Cruz 99:227-231. https:// doi.org/10.1590/S0074-02762004000200020

22. Rodríguez-Hahn L, Cárdenas J, Arenas C (1996) Trichavensin, a prieurianin derivative from Trichilia havanensis. Phytochem 43:457-459. https://doi.org/10.1016/0031-9422(96)00245-2 
23. Rodríguez B, Caballero C, Ortego F, Castañera P (2003) A new tetranortriterpenoid from Trichilia havanensis. J Nat Prod 66:452454. https://doi.org/10.1021/np0204646

24. Paritala V, Chiruvella KK, Thammineni C, Ghanta R, Mohammed A (2015) Phytochemicals and antimicrobial potentials of Mahogany family. Rev Braz Farmacogn 25:61-83. https://doi. org/10.1016/j.bjp.2014.11.009

25. Salehi B, Zakaria ZA, Gyawali R, Ibrahim SA, Rajkovic J, Shinwari ZK, Khan T, Sharifi-Rad J, Ozleyen A, Turkdonmez E, Valussi M, Tumer TB, Fidalgo LM, Martorell M, Setzer WN (2019) Piper species: a comprehensive review on their phytochemistry, biological activities and applications. Molecules 24:1364. https://doi.org/10.3390/molecules24071364

26. Svetaz L, Zuljan F, Derita M, Petenatti E, Tamayo G, Cáceres A, Filho VC, Giménez A, Pinzón R, Zacchino SA, Gupta M (2010) Value of the ethnomedical information for the discovery of plants with antifungal properties. A survey among seven Latin American countries. J Ethnopharmacol 127:137-158. https://doi.org/10. 1016/j.jep.2009.09.034

27. Cruz SM, Cáceres A, Álvarez L, Morales J, Apel MA, Henriques AT, Salamanca E, Giménez A, Vásquez Y, Gupta MP (2011) Chemical composition of essential oils of Piper jacquemontianum and Piper variabile from Guatemala and bioactivity of the dichloromethane and methanol extracts. Braz J Pharmacogn 21:587-593

28. Santana AI, Vila R, Cañigueral S, Gupta MP (2016) Chemical composition and biological activity of essential oils from different species of Piper from Panama. Planta Med 82:986-991. https:// doi.org/10.1055/s-0042-108060

29. Puhl MCMN, Cortez DAG, Ueda-Nakamura T, Nakamura CV, Filho BPD (2011) Antimicrobial activity of Piper gaudichaudianum Kuntze and its synergism with different antibiotics. Molecules 16:9925-9938. https://doi.org/10.3390/molecules161299 25

30. Gaia AM, Yamaguchi LF, Jeffrey CS, Kato MJ (2014) Agedependent changes from allylphenol to prenylated benzoic acid production in Piper gaudichaudianum Kunth. Phytochem 106:8693. https://doi.org/10.1016/j.phytochem.2014.06.013

31. Caceres A, Cruz SM, Martinez-Arevalo JV, Henriques AT, Apel MA (2019) Composition of essential oil from Piper jacquemontianum from eight provenances of Guatemala. Nat Prod Commun 14:75-78. https://doi.org/10.1177/1934578X1901400120

32. Villamizar LH, Cardoso MG, de Andrade J, Teixeira ML, Soares MJ (2017) Linalool, a Piper aduncum essential oil component, has selective activity against Trypanosoma cruzi trypomastigote forms at $4{ }^{\circ} \mathrm{C}$. Mem Inst Oswaldo Cruz 112:131-139. https://doi. org/10.1590/0074-02760160360

33. Ramos CS, Vanin SA, Kato MJ (2009) Sequestration of prenylated benzoic acid and chromenes by Naupactus bipes (Coleoptera: Curculionidae) feeding on Piper gaudichaudianum (Piperaceae). Chemoecology 19:73-80. https://doi.org/10.1007/ s00049-009-0011-0

34. Jung JH, Pummangura S, Chaichantipyuth $\mathrm{C}$, Patarapanich $\mathrm{C}$, McLaughlin JL (1990) Bioactive constituents of Melodorum fruticosum. Phytochem 29:1667-1670. https://doi.org/10.1016/ 0031-9422(90)80142-4

35. Lago JHG, Chen A, Young MCM, Guimaraes EF, de Oliveira A, Kato MJ (2009) Prenylated benzoic acid derivatives from Piper aduncum L. and P. hostmannianum C. DC. (Piperaceae). Phytochem Let 2:96-98. https://doi.org/10.1016/j.phytol.2009.01.001

36. Napal GND, Defagó MT, Valladares GR, Palacios SM (2010) Response of Epilachna paenulata to two flavonoids, pinocembrin and quercetin, in a comparative study. J Chem Ecol 36:898-904. https://doi.org/10.1007/s10886-010-9823-1

37. Su BN, Park EJ, Vigo JS, Graham JG, de Cabieses F, Fong HHS, Pezzuto JM, Kinghorn AD (2003) Activity-guided isolation of the chemical constituents of Muntingia calabura using a quinone reductase induction assay. Phytochem 63:335-341. https://doi.org/ 10.1016/S003-9422(03)00112-2

38. Ruiz C, Haddad M, Alban J, Bourdy G, Reategui R, Castillo D, Sauvain M, Deharo E, Estevez Y, Arevalo J, Rojas R (2011) Activity-guided isolation of antileishmanial compounds from Piper hispidum. Phytochem Lett 4:363-366. https://doi.org/10. 1016/j.phytol.2011.08.001

39. de Castro CCB, Costa PS, Laktin GT, de Carvalho PHD, Geraldo RB, de Moraes J, Pinto PLS, Couri MRC, Pinto PF, Filho AAS (2015) Cardamonin, a schistosomicidal chalcone from Piper aduncum L. (Piperaceae) that inhibits Schistosoma mansoni ATP diphosphohydrolase. Phytomedicine 22:921-928. https://doi.org/ 10.1016/j.phymed.2015.06.009

40. de Mello MVP, Abrahim-Vieira BdA, Domingos TFS, de Jesus JB, de Sousa ACC, Rodrigues CR, de Souza AMT (2018) A comprehensive review of chalcone derivatives as antileishmanial agents. Eur J Med Chem 25:920-929. https://doi.org/10.1016/j. ejmech.2018.03.047

41. Roussis V, Ampofo SA, Wiemer DF (1990) A prenylated benzoic acid derivative from the leaves of Piper taboganum. Phytochem 29:1787-1788. https://doi.org/10.1016/0031-9422(90)85016-9

42. Terreaux C, Gupta MP, Hostettmann K (1998) Antifungal benzoic acid derivatives from Piper dilatatum. Phytochem 49:461-464. https://doi.org/10.1016/S0031-9422(98)00197-6

43. Mazzeu BF, Felippe LG, Cotinguiba F, Kato MJ, Furlan M (2018) Kavalactones and benzoic acid derivatives from leaves of Piper fuligineum Kunth (Piperaceae). J Braz Chem Soc 29:1286-1290. https://doi.org/10.21577/0103-5053.20170225

44. Xiao H, Rao R, Ravu Tekwani BL, Li W, Liu WB, Jacob MR, Khan SI, Cai X, Peng CY, Khan IA, Li XC, Wang W (2017) Biological evaluation of phytoconstituents from Polygonum hydropiper. Nat Prod Res 31:2053-2057. https://doi.org/10.1080/14786 419.2016.1269094

45. Passalacqua TG, Dutra LA, de Almeida L, Velásquez AMA, Torres FAE, Yamasaki PR, dos Santos MB, Regasini LO, Michels PAM, Bolzani VdS, Graminha MA (2015) Synthesis and evaluation of novel prenylated chalcone derivatives as anti-leishmanial and anti-trypanosomal compounds. Bioorg Med Chem Lett 25:3342-3345. https://doi.org/10.1016/j.bmcl.2015.05.072

46. Gomes KS, da Costa-Silva TA, Oliveira IH, Aguilar AM, OliveiraSilva D, Uemi M, Silva WA, Melo LR, Andrade CKZ, Tempone AG, Baldim JL, Lago JHG (2019) Structure-activity relationship study of antitrypanosomal chalcone derivatives using multivariate analysis. Bioorg Med Chem Lett 29:1459-1462. https://doi.org/ 10.1016/j.bmcl.2019.04.020

47. Qiao Z, Wang Q, Zhang F, Wang Z, Bowling T, Nare B, Jacobs RT, Zhang J, Ding D, Liu Y, Zhou H (2012) Chalcone-benzoxaborole hybrid molecules as potent antitrypanosomal agents. J Med Chem 55:3553-3557. https://doi.org/10.1021/jm2012408

48. Roussaki M, Hall B, Lima SC, da Silva AC, Wilkinson S, Detsi A (2013) Synthesis and anti-parasitic activity of a novel quinolinone-chalcone series. Bioorg Med Chem Lett 23:6436-6441. https://doi.org/10.1016/j.bmcl.2013.09.047

49. Zulu AI, Oderinlo OO, Kruger C, Isaacs M, Hoppe HC, Smith VJ, Veale CGL, Khanye SD (2020) Synthesis, structure and in vitro anti-trypanosomal activity of non-toxic arylpyrrole-based chalcone derivatives. Molecules 25:1668. https://doi.org/10.3390/ molecules 25071668

Publisher's Note Springer Nature remains neutral with regard to jurisdictional claims in published maps and institutional affiliations. 